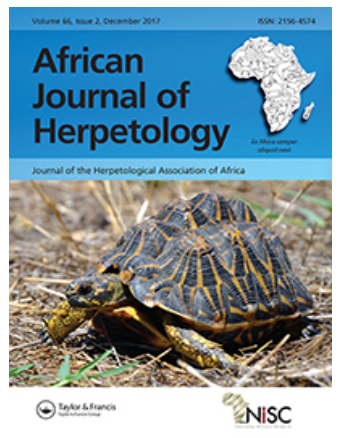

African Journal of Herpetology

ISSN: 2156-4574 (Print) 2153-3660 (Online) Journal homepage: http://www.tandfonline.com/loi/ther20

\title{
Cyclic variation of the oviduct structure of Boulengerula taitana, an oviparous species of Gymnophiona: morphological changes, proliferation and apoptosis
}

\author{
C. Brun, M.A. Raquet, G.J. Measey \& J.M. Exbrayat
}

To cite this article: C. Brun, M.A. Raquet, G.J. Measey \& J.M. Exbrayat (2017) Cyclic variation of the oviduct structure of Boulengerula taitana, an oviparous species of Gymnophiona: morphological changes, proliferation and apoptosis, African Journal of Herpetology, 66:2, 93-105, DOI:

10.1080/21564574.2017.1365098

To link to this article: https://doi.org/10.1080/21564574.2017.1365098

Published online: 27 Nov 2017.

Submit your article to this journal ¿

Џ Article views: 80

Q View related articles $\sqsubset$

View Crossmark data ¿

Full Terms \& Conditions of access and use can be found at

http://www.tandfonline.com/action/journallnformation?journalCode=ther20 


\title{
Cyclic variation of the oviduct structure of Boulengerula taitana, an oviparous species of Gymnophiona: morphological changes, proliferation and apoptosis
}

\author{
C. Brun ${ }^{1 *}$, M.A. Raquet ${ }^{1}$, G.J. Measey ${ }^{2} \&$ J.M. Exbrayat ${ }^{1}$ \\ ${ }^{1}$ Université de Lyon, UMRS 449, Biologie générale, Reproduction et développement comparé, UCLy, EPHE/PSL, \\ 10 place des Archives, F-69288 Lyon cedex 02, France; ${ }^{2}$ Centre for Invasion Biology, Department of Botany and \\ Zoology, Stellenbosch University, Stellenbosch, South Africa
}

\begin{abstract}
Functioning of the amphibian oviduct is the subject of many studies, but detailed understanding of caecilian reproduction exists for very few species. In this study, a description is made of morphological changes of the oviduct of the caecilian Boulengerula taitana throughout the year, using conventional histology and immunohistochemistry. The reproductive cycle of this little-known species, originating from the Taita Hills in southeast Kenya, is annual. During the reproductive period (November-February), both lamina propria and the epithelium of the oviduct exhibit a maximum degree of development. The epithelial mucosa is more secretory and the cilia cells are abundant. Histological analysis shows the distribution of the different type of cells according to a specific pattern in the pars recta, pars convoluta and pars utera. Evaluation of proliferative (Ki-67 positive cells) and apoptotic cells (TUNEL and Apostain assays) into the different tissues brings out cyclic modifications of the lamina propria and epithelial cells throughout a seasonal cycle. The results demonstrate that the balance between cell proliferation and apoptosis reflects the functionality of the oviduct during the sexual cycle.
\end{abstract}

Key words.-apoptosis; cell proliferation; Gymnophiona; Herpelidae; histology; immunohistochemistry; oviduct.

\section{INTRODUCTION}

The oviduct is a physiological site for key events in reproduction. For select species, including Gymnophiona, it is the place where fertilisation and early embryonic development take place. To fulfil this role, the oviduct must undergo dynamic changes during the ovarian cycle and pregnancy. Cell proliferation and degeneration are characteristic of the morphological and functional changes of the oviducts (Exbrayat, 2006a).

In multicellular organisms, apoptosis is the main cell death mechanism required to regulate tissue regeneration during physiological processes. It plays a key role in maintaining cell homeostasis and remodelling. In mammalian oviduct, several authors have demonstrated the proliferation of epithelial cells under high oestrogen levels and the regression of cells under high progesterone levels (Steffl et al. 2008). However, few studies exist on

*Corresponding author. Email: cbrun@univ-catholyon.fr 
dynamic cell movements in amphibian genital tracts, especially among the Gymnophiona (Wake \& Dickie, 1998; Exbrayat, 2006b; Gomes et al. 2012).

Caecilians (Amphibia: Gymnophiona) are elongate, limbless, wormlike amphibians living primarily in tropical areas. They practice different reproductive modes following internal insemination (Exbrayat, 2006b). Boulengerula taitana, a species endemic to the Taita Hills of southeast Kenya, is a direct-developing oviparous caecilian. Its sexual cycle is annual and is divided into three periods: preparation from September to October, ovulation from November to February and rest from March to August (Malonza \& Measey, 2005; Measey et al. 2008; Raquet et al. 2015).

Oviducts of Gymnophionans are elongate, lying laterally to the kidneys and ovaries. The anterior part is situated near the heart and consists of the ostium; the posterior part of the oviduct ends in the cloaca. In oviparous species, the oviduct is differentiated into three segments-anterior, middle and posterior parts-called, respectively, the pars recta, pars convoluta and pars utera (Wake, 1970; Exbrayat, 2006a, Raquet et al. 2011). Each segment possesses a serosa, a thin muscular layer and a mucosa. The folds of the mucosal layer are covered with a pseudo-stratified epithelium and supported by the loose tissue of the lamina propria, which penetrates into the mucosal folds. Cell composition of the epithelium depends on the segment considered (Wake, 1970; Exbrayat, 1989; Masood-Parveez \& Nadkarni, 1991; Wake \& Dickie, 1998). Microscopic observations of the Boulengerula taitana oviduct in February (at the end of ovulation) shows that the pars recta contains few ciliated cells and mainly large glandular cells, the pars convoluta consists of two types of glandular cells - secretory and goblet cells-in addition to ciliated cells, while only one type of glandular cell is found in the pars utera. On the other hand, the transitions between the oviductal segments are not distinct and the characteristics of histological structures are mixed (Raquet et al. 2011).

The aim of this study was first to describe the histological structure of the oviduct and the changes in biochemical characteristics of secretory cells in the different parts of the oviduct, according to the breeding cycle. Secondly, it was to link the morphological phases of oviductal evolution with apoptosis and proliferation.

\section{Material And Methods}

\section{Animals}

Specimens of Boulengerula taitana were collected in the Taita Hills, Kenia, from April 2003 to March 2004 (see Malonza \& Measey, 2005 for details). Specimens were immediately anaesthetised with MS222 (Sigma Aldrich, St Louis, MO, USA), measured and fixed in formaldehyde (10\%). Animals with total body lengths less than $211 \pm 4.81 \mathrm{~mm}$ were eliminated from this study in order to avoid the presence of immature animals.

\section{Histomorphological Analysis}

The left oviduct was dissected free from the ovary, weighed and measured. It was then embedded in paraffin and cut in transversal sections $(7 \mu \mathrm{m})$. The sections were stained either with Romeis' azan and Masson-Goldner's trichrome for topographic examination, or with histochemical dyes for carbohydrate determination of the mucous secretions. 
Periodic acid-Schiff (PAS) was performed to identify the cell polysaccharides, alcian bluePAS to visualise the simple monosaccharides and acidic carbohydrates, Ravetto's staining to label the sulphated carbohydrates at $\mathrm{pH} 0.5$ or the specifically carboxyled carbohydrates at $\mathrm{pH} 2.5$ (Exbrayat, 2013).

\section{Quantification of Apoptosis}

Apoptotic cells were identified using two different procedures, based on the DNA fragmentation into characteristic fragments: the TUNEL-method (using the terminal deoxyribonucleotidyl transferase (TdT)-mediated dUTP-digoxigenin nick end-labelling) and the Apostain assay (involving a formamide-based DNA-denaturation).

Staining with Apostain kit was performed following the manufacturer's instructions (Eurobio-AbCys, Courtaboeuf, France). After deparaffinisation and rehydration, slides were treated with a solution of proteinase $\mathrm{K}(20 \mu \mathrm{g} / \mathrm{mL})$ for $20 \mathrm{~min}$. at room temperature and heated in formamide $\left(58^{\circ} \mathrm{C}\right)$ for $20 \mathrm{~min}$. After heating, they were transferred into icecold phosphate-buffered saline (PBS), treated with $3 \% \mathrm{H}_{2} \mathrm{O}_{2}$ for 5 min., blocked in $3 \%$ dry fat-free milk, stained with monoclonal antibody Apostain $(1 \mathrm{mg} / \mathrm{mL}$ in PBS, Eurobio-AbCys, Courtaboeuf, France) for $30 \mathrm{~min}$. at room temperature. Normal serum was added to negative controls instead of anti-ssDNA antibody. After washing, peroxidase-conjugated anti-mouse IgM (1:500 in PBS, Merck Millipore, France) was applied for 30 minutes at room temperature. A solution of 3, 3' Diaminobenzidine (DAB) (Roche Diagnostics, Basel, Switzerland) was used as horseradish peroxidase (HRP) chromogen and hematoxylin QS (Vector Laboratories, Burlingame, CA, USA) as a counterstain.

TUNEL staining was performed using the Roche diagnostic kit on deparaffinised sections pretreated with proteinase- $\mathrm{K}\left(20 \mu \mathrm{g} / \mathrm{mL}, 30 \mathrm{~min}\right.$. at $\left.37{ }^{\circ} \mathrm{C}\right)$ and $\mathrm{H}_{2} \mathrm{O}_{2}(3 \%, 5 \mathrm{~min}$. at room temperature). Each sample was incubated with TUNEL reaction mixture (terminal deoxynucleotidyl transferase (TdT) and modified FITC nucleotides in appropriate concentration) in a wet chamber for $1 \mathrm{~h}$ at $37^{\circ} \mathrm{C}$. The reaction was stopped with stop-buffer solution (30 min., room temperature). After being washed in PBS, the tissue sections were incubated with peroxidase-conjugated anti-fluorescein antibodies $\left(30 \mathrm{~min} ., 37{ }^{\circ} \mathrm{C}\right.$ ), washed three times; peroxidase was revealed in DAB solution. Hematoxylin QS (Vector laboratories, Burlingame, CA, USA) was used as a counterstaining. A positive control (sections incubated with DNase I $3000 \mathrm{U} / \mathrm{mL}$ prior to labelling procedure) and a negative control (sections incubated with label solution only instead of TUNEL reaction mixture) were included.

\section{Evaluation of Proliferation}

An immunohistochemical method was used to investigate cell proliferation. Slides were deparaffinised, rehydrated in PBS (0.1 M, pH 7.4), incubated in $3 \% \mathrm{H}_{2} \mathrm{O}_{2}$, washed in PBS for $5 \mathrm{~min}$. and subjected to antigen retrieval (microwave $800 \mathrm{w}, 10 \mathrm{~min}$.). The sections were incubated for 5 minutes with BSA and stained for $1 \mathrm{~h}$ at room temperature with antiKi67 monoclonal antibodies (1:100; AbcysVP-RM04, Abcys, les Ulis, France). Speciesspecific isotype controls were used as negative controls. The slides were then washed in PBS and immunoreactions were visualised with a streptavidin-biotin amplification kit 
using AEC as the chromogen (Kit VECTASTAIN Elite ABC kit, Vector laboratories, Peterborough, UK).

\section{Statistical Analysis}

For each slide examined with a light microscope, the number of apoptosis or proliferating positive cells per 30 cells was counted in each cell type. The Nis element BR software (Nikon) was used. The mean value was calculated and a 95\% confidence interval was determined. The significance of differences between means was estimated with Fisher's Least Significant Difference (LSD) test. Differences were considered as significant for $P<0.05$.

\section{Results}

\section{Biometric Data}

The average length of oviducts was $88.8 \pm 5.9 \mathrm{~mm}$, without any significant variation throughout the year and without important correlation $(27.7 \%)$ with the total length of females $(N=29, P=0.003)$ and with the average mass of oviducts $(18.3 \% ; N=31$, $P=0.016)$. Because of this variability, two weight classes of average mass of oviducts were created: (i) a class in which the oviduct mass was high $(29.9 \pm 16.9 \mathrm{mg})$, corresponding to the oviducts of animals caught from November until February, and (ii) a class in which the oviduct mass was low $(6.0 \pm 2.8 \mathrm{mg})$, corresponding to the oviducts of animals caught from March until October.

The observation of transverse sections with the light microscope showed a large disparity of several parameters according to the month. The total diameter of section varied from $1023 \pm 105 \mu \mathrm{m}$ to $170 \pm 9 \mu \mathrm{m}$, the thickness of the oviduct wall varied from $38.0 \pm 7.6 \mu \mathrm{m}$ to $23 \pm 1.4 \mu \mathrm{m}$. The narrowest sections were found from March until August, and the largest from September until February. In February, eggs were observed in some oviducts.

\section{General Histological Structure}

Histological observations showed that the epithelium and the lamina propria underwent morphological changes throughout the year. Between November and February, the oviduct exhibited the highest degree of development of secretory cells containing a large number of granules. This allowed us to describe general structures of the oviduct.

Pars recta.-The pars recta represented 10 to $20 \%$ of the distal length of the oviduct according to the period of year. This part undulated slightly. The lumen was slightly pleated and bordered by a columnar epithelium composed of ciliated cells and gland cells disposed between the villi forming some crypts (Fig. 1A). Gland cells measured $70 \mu \mathrm{m}$ high, with a basal nucleus $(5 \mu \mathrm{m})$. The cytoplasm was characterised by the presence of tiny granulations stained purple with the combined alcian blue-PAS staining. In some of them, the cytoplasm contained a large vacuole stained blue, yellow or green with Ravetto's staining. These results were characteristic of both sulphate and/or carboxylic acidic proteoglycans. The limits of cells were fuzzy, suggesting that the secretion was of the holocrine type, with the elimination of the whole cell, or apocrine with only the 

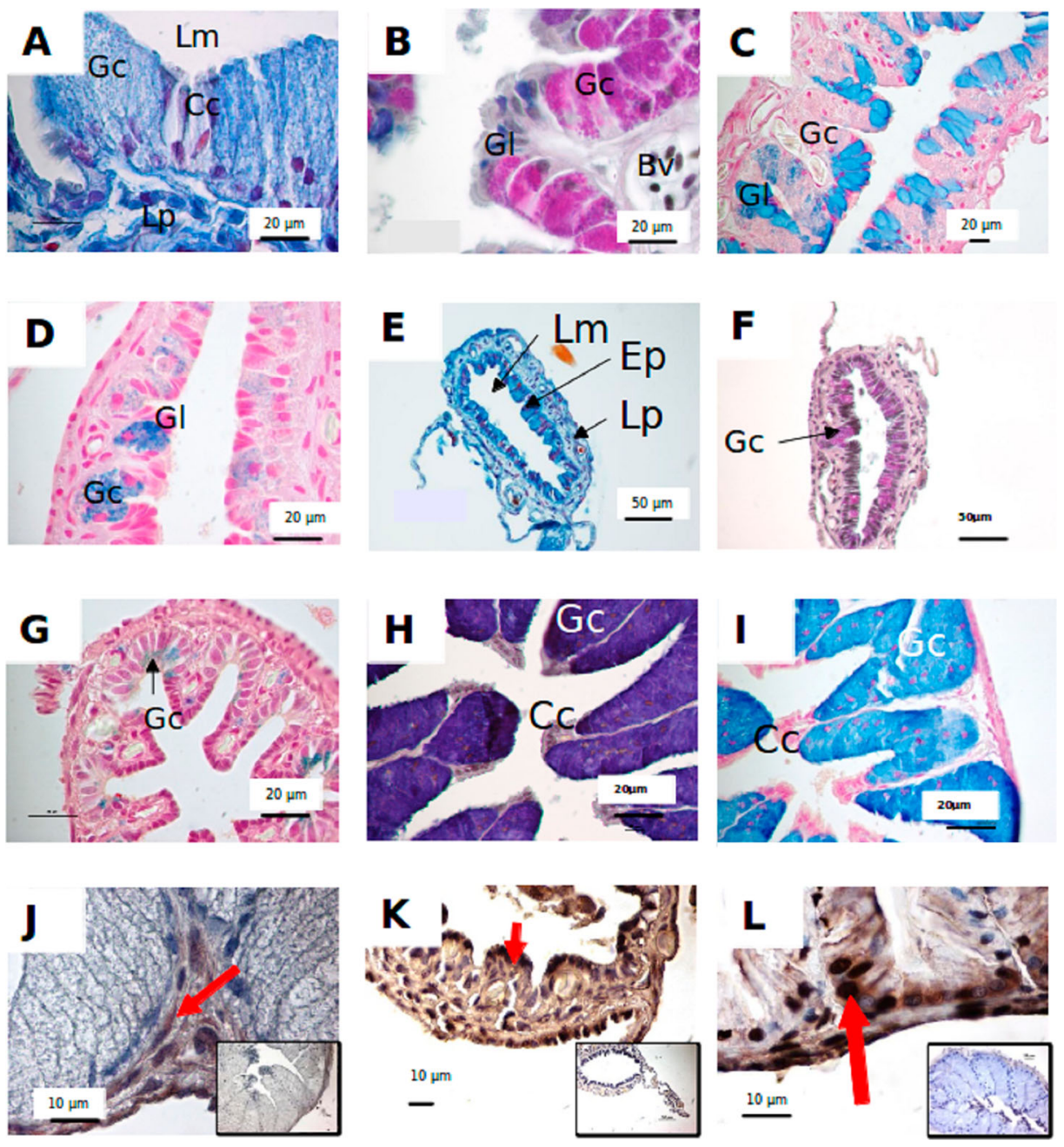

Figure 1. A, pars recta, February, azan staining. B, pars convoluta, January, alcian blue-PAS staining. C, pars convoluta, February, Ravetto's staining. D, pars convoluta, June, Ravetto's staining. E, pars convoluta, August, azan staining. F, pars convoluta, June, Ravetto's staining. G, pars utera, May, Ravetto's staining. H, pars utera, September, alcian blue-PAS staining. I, pars utera, September, Ravetto's staining. J, pars recta, September, Ki67 detection. K, pars convoluta, June, TUNEL reaction. L, pars utera, November, Apostain. The small lower right image is the control slide.

[Bv, blood vessel; Cc, ciliated cell; Ep, epithelium; Gc, goblet cell; Gl, gland cell; Lm, lumen; Lp, lamina propria]

amputation of the apical part of the cell, which was strengthened by the absence of cell debris into the lumen.

Pars convoluta.- The pars convoluta was the middle $35-40 \%$ total length of oviduct. The lumen was bordered with well-developed villi or rounded fingerings (Fig. 1C). The connective tissue was thick, with particularly wide blood vessels just under the crests of the villi. The epithelium was constituted by ciliated cells intercalated with goblet and secreting cells. The goblet cells were small with a central nucleus. The cytoplasm expanded near the 
lumen with secretions which were PAS positive, stained with alcian blue and Ravetto's staining, showing the presence of both sulphate and carboxylic acidic proteoglycans (Fig. 1B and 1C). The gland cells situated between the villi, forming crypts, were high (24-32 $\mu \mathrm{m}$ high) with a basal nucleus (4-6\% $\mu \mathrm{m}$ diameter), and an abundant often granular cytoplasm which was blue-stained with azan trichrome and PAS positive; neither alcian blue nor Ravetto's staining gave them any colour.

Pars utera.- - The pars utera representing the anterior $35-40 \%$ total length was well fingered with a single gland cell type (Fig. 1I). The lumen was bordered with flattened high crests covered with ciliated cells. A wide blood vessel was observed under each connective crest. The chorion looked as if it was crushed by glands disposed in crypts, with a single cell type (the third type) measuring $80 \mu \mathrm{m}$ high, $18 \mu \mathrm{m}$ wide, with a basal nucleus situated at the bottom of the villi. The secretions of these cells were well stained with azan, alcian blue and Ravetto's staining, showing the presence of both sulphate and carboxylic acidic secretions.

In addition to these three main parts, some intermediary zones were more or less differentiated throughout the year. The transition between the ostium and pars recta was notably rapid.

\section{Cyclic Modifications}

Between March and August, the oviduct diameter varied between 120 and $170 \mu \mathrm{m}$. In July, its development was at the lowest. Whatever the part, the slightly developed epithelium bordered a narrow lumen; the lamina propria was narrow and contained few blood vessels (Fig. 1E). In the pars recta, the number of crypts became limited and shallow. The surface epithelium of the pars recta contained some clusters of ciliated cells and secretory cells with a large nucleus forming projections into the lumen and a reduced cytoplasm. The ciliated cells of the pars convoluta did not present any cilium and contained dark stained basal bodies; some granules containing carboxylic carbohydrates were found in the cytoplasm. The goblet cells showed mainly sulphated proteoglycans (Fig. $1 \mathrm{D}$ and $1 \mathrm{~F}$ ). In secretory cells found in the crypts, the cytoplasm contained some granulations and the nucleus appeared frequently pyknotic. During this period, the pars utera was the most folded segment of the oviduct: it exhibited crypt-like invaginations in the dense connective tissue; the lumen contained cell fragments. The cytoplasm of the de-ciliated cells was reduced. The secretory cells with a nucleus, often intensely condensed, contained some granules with various proteoglycan blue-green labelled with Ravetto's staining and purple-stained with alcian blue-APS, showing a mixture of neutral, carboxylic and sulphated glycoproteins (Fig. 1G).

In September-October, the oviduct lengthened and became more tortuous (Fig. 1H and 1I). The lamina propria got thicker, the diameter of the lumen increased $(500 \mu \mathrm{m}$ in October) and the epithelium became thickest. The secretory cells of the pars recta increased in size; the alcian blue and Ravetto's staining gave more intense results than in the previous period. The pars convoluta exhibited an important degree of development of both ciliature and secretory cells. The crypts expanded. Acidic carbohydrates were detected in the cytoplasm of ciliated cells which were blue stained with alcian blue. The secretory cells became larger and the cytoplasmic granules increased in density. The lumen of the epithelium contained some cell fragments. The goblet cells were purple 
stained with alcian blue-PAS. The secretory cells were arranged in cluster into the crypts of the pars utera. They showed a slight staining with alcian blue-PAS and Ravetto's methods, suggesting a limited synthesis of carboxylic and sulphated proteoglycans (Fig. 1H and 1I). The number of ciliated cells was in progress on the epithelium surface.

\section{Apoptosis and Proliferation Evaluation}

Figures $1 \mathrm{~J}, 1 \mathrm{~K}$ and $1 \mathrm{~L}$ show histological slides marked with antibodies against Ki-67, with TUNEL and Apostain treatments.

Apoptosis and proliferation evaluation of the lamina propria cells. - The number of Ki-67 positive cells varied considerably during the year and this evolution was significant (pars recta, $N=9, P<0.0001$; pars convoluta, $N=7, P=0.002$; pars utera, $N=7, P=0.001)$. Whichever part of oviduct was observed, the largest percentage of Ki-67 positive cells occurred during September-October and November-February (Fig. 1J, 2A, 3A and 4A). It decreased during March-August. TUNEL and Apostain-positive cells were detected in all the oviduct parts (Fig. 1K and 1L). The number of apoptotic cells out of 100 cells was significant throughout the year. Thereby in pars recta, the apoptotic cells were more abundant than proliferating cells during March-August, less abundant during September-October and similar during November-February (Fig. 2A). In pars convoluta, only the number of proliferating cells fluctuated between the periods of rest and preparation, the number of apoptotic cells being comparable without significant variation between seasons (Fig. 3A). In pars utera, a large increase of proliferating cells was observed after the resting period, and a slight significant increase of apoptotic cells was found after the period of breeding preparation $(N=6, P=0.034$ for TUNEL method). The number of apoptotic cells was not significantly different between the periods of rest and preparation (Fig. 4A).

Apoptosis and proliferation evaluation of the secretory cells. - During the year, the number of proliferating cells evolved differently between the three segments of the oviduct (Fig. 2B, 3B and 4B). In pars recta, there was no significant change in the number of mitotic nuclei during the year. The proliferation index was greater than the number of apoptotic cells counted during March-August, and equal during the other months (Fig. 2B). On the contrary, in both pars convoluta and pars utera, the number of Ki-67-positive cells was close to zero during March-August, and increased substantially during the following months. In pars recta and pars convoluta, both proliferating and apoptotic cells were most frequently visualised during November-February; in pars utera, they were visualised in September-October (Fig. 2B, 3B and 4B).

Apoptosis and proliferation evaluation of the goblet cells.-Goblet cells were found only in the pars convoluta. In March-August no proliferating cells were detected, in September-October the numbers of proliferating and apoptotic cells were the same, in November-February a significant number of proliferating cells was counted (Fig. 3D). The percentage of Ki-67 positive cells increased significantly through the year $(N=6 ; P=$ 0.02 ); it rose from $1 \%$ in March-August to $12 \%$ in September-October and $60 \%$ in November-February. Inversely, the percentage of apoptosis cells decreased by $53 \%$, $15 \%$ and $18 \%$ during these same periods; these variations were not significant between September-October and November-February $(N=7, P=0.526$ for TUNEL method). 




Figure 2. Number of proliferating (Ki67-positive) and apoptotic (TUNEL-positive and Apostainpositive) cells in the Boulengerula taitana oviduct (pars recta) throughout a seasonal cycle (12 months). Each value was determined with a $95 \%$ confidence interval. A, lamina propria $(N=9)$; B, secretory cells $(N=6)$; $\mathrm{C}$, ciliated cells $(N=8)$. 

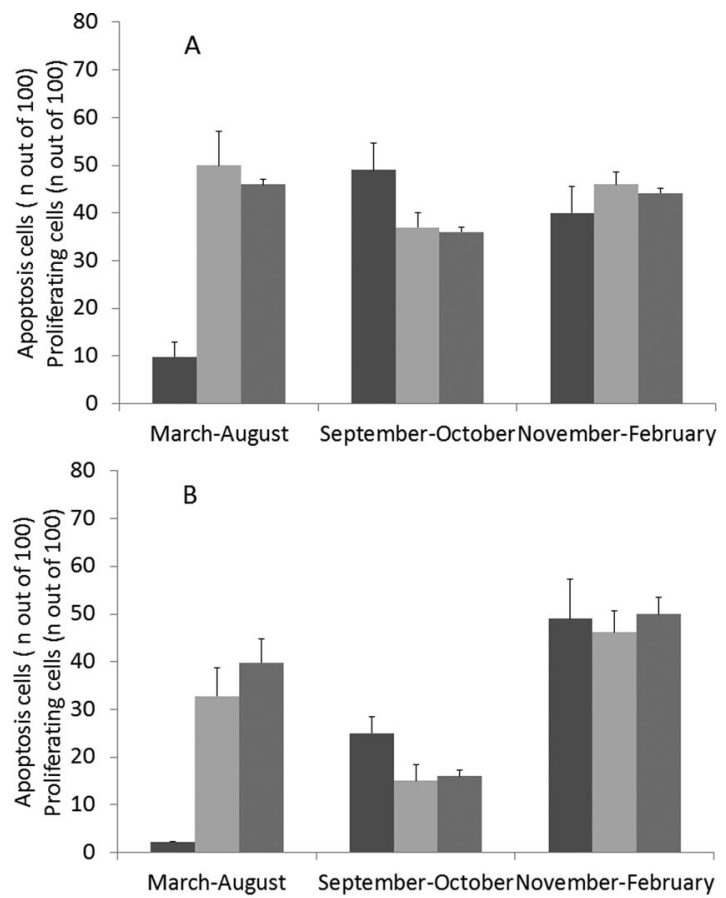

\section{- Proliferation}

apoptosis TUNEL

apoptosis Apostain
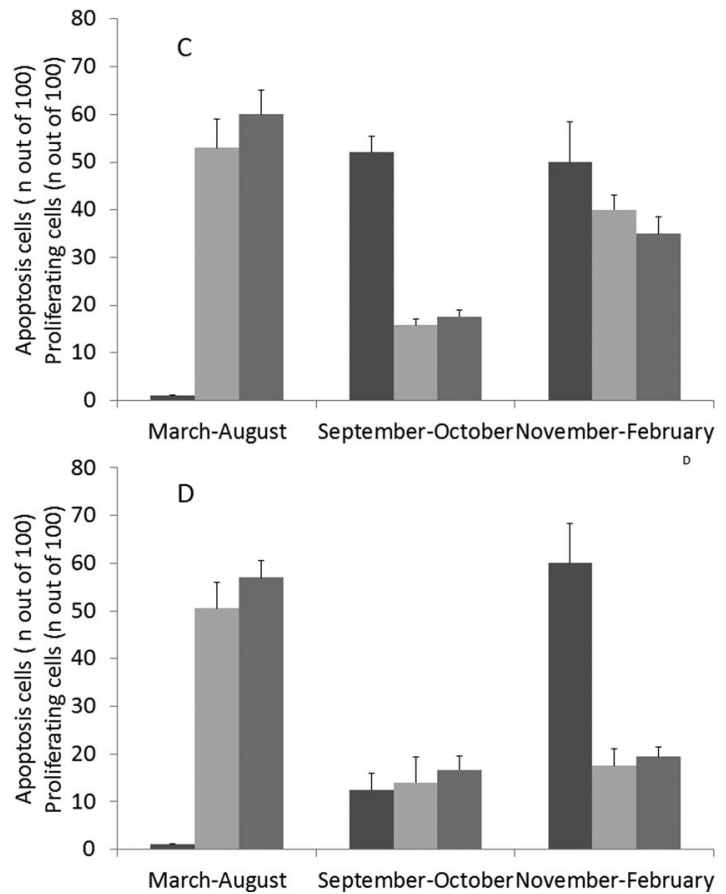

- Proliferation

Apoptosis TUNEL

Apoptosis Apostain

Figure 3. Number of proliferating (Ki67-positive) cells and apoptotic (TUNEL-positive and Apostain-positive) cells in the Boulengerula taitana oviduct (pars convoluta) throughout a seasonal cycle (12 months). Each value was determined with a $95 \%$ confidence interval. A, lamina propria $(N=7)$; B, secretory cells $(N=8)$; C, ciliated cells, $(N=8)$; D, goblet cells $(N=7)$. 


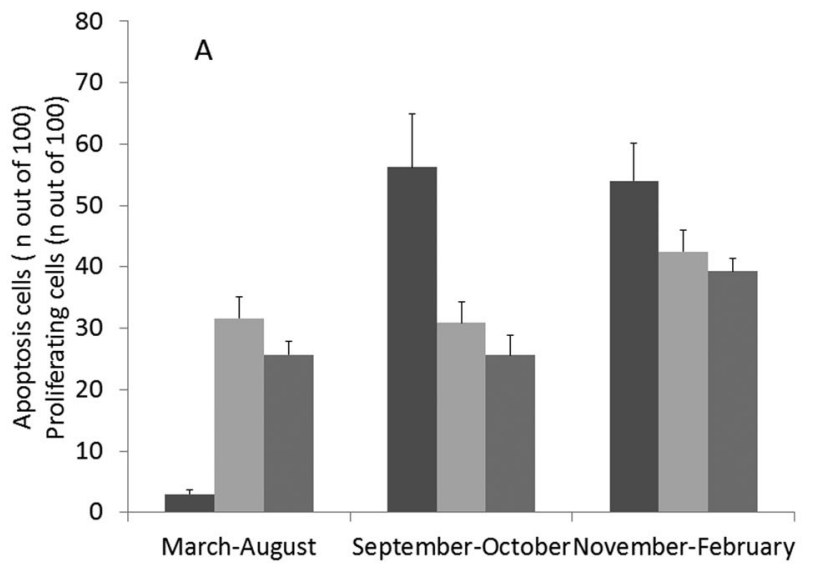

- Proliferation

$\square$ Apoptosis TUNEL

Apoptosis Apostain
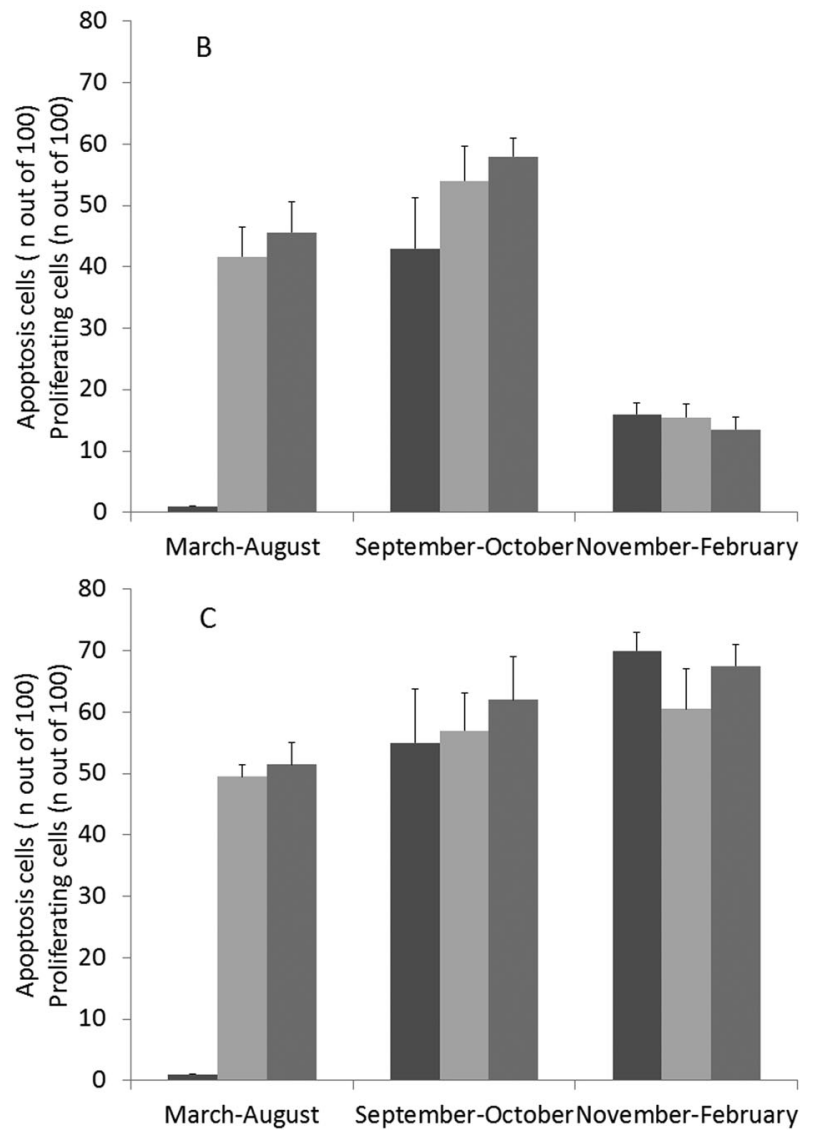

- Proliferation

Apoptosis TUNEL

Apoptosis Apostain
- Proliferation

apoptosis TUNEL

apoptosis Apostain

Figure 4. Number of proliferating (Ki67-positive) cells and apoptotic (TUNEL-positive and Apostain-positive) cells in the Boulengerula taitana oviduct (pars utera) throughout a seasonal cycle (12 months). Each value was determined with a $95 \%$ confidence interval. A, lamina propria $(N=7)$; $\mathrm{B}$, secretory cells $(N=7)$; $\mathrm{C}$, ciliated cells $(N=8)$. 
Evaluation of apoptosis and proliferation of the ciliated cells. - Whatever the period of year, proliferating ciliated cells were more frequently counted in the pars recta than apoptotic ones (Fig. 2C). In this segment, the number of proliferating and apoptotic cells increased substantially during November-February, reflecting a strong activity of these cells during the breeding period. In the two other segments, the ciliated cells showed surprisingly virtually no proliferation activity in March-August, while $60 \%$ (pars convoluta) and $49.5 \%$ of these cells (pars utera) were Apostain-positive cells (Fig. 3C and 4C). In these middle and posterior parts of the oviduct, proliferation indexes were $52 \%$ (pars convoluta) and 55\% (pars utera) in September-October and indexes were, respectively, 55\% and $70 \%$ in November-February. All these annual variations were significant in each part of the oviduct $(N=8, P=0.001$, pars recta; $N=5, P=0.006$, pars convoluta; $N=8, P<$ 0.0001 , pars utera). Comparatively, apoptosis affected $17.6 \%$ of cells (Apostain method) in pars convoluta and 62\% in pars utera in September-October; indexes were respectively $35 \%$ and $67.5 \%$ in November-February. The evolution of apoptotic cell number was significant through the year in pars recta and pars convoluta $(N=6, P=0.001$, pars recta; $N=6, P=0.001$, pars convoluta $)$ but not significant in pars utera $(N=6, P=0.125)$.

\section{Discussion}

The histological observations confirmed that the genital tract of Boulengerula taitana is subject to dynamic changes throughout the year. The relative mass and diameter of each part of the oviduct and the height of the oviduct glands all varied according to the month. The minimum values were observed from March to August, and they increased gradually from September to October to reach a maximum level between November and February. These results are consistent with the three periods described in a previous study of the ovaries, the young corpora lutea being detected between November and February only (Raquet et al. 2015), which was the ovulation period. Then a rest period occurred (March-August) until a short transition period (September-October).

As ovulation approached, the oviducts became more convoluted; the epithelial mucosa was more secretory and the cilia of cells became important. These cyclic changes, linked to the reproductive cycle, were similar to those described in Ichthyophis beddomei, another oviparous Gymnophionan (Masood-Parveez \& Nadkarni, 1991).

The quantification of apoptosis was carried out with two complementary techniques TUNEL and Apostain methods. The TUNEL reaction is a commonly used technique, but it was reported to label not only apoptotic, but also necrotic or oncotic derived DNA strand breakages (Rodriguez \& Shaper, 2005; Taatjes et al. 2008). So, an additional measurement based on early detection of apoptosis was used in addition to TUNEL. The results showed that both techniques were positively correlated in every tissue of the oviduct and in accordance with histological observations.

The measurement of proliferating and apoptotic cells confirmed that the Boulengerula taitana oviduct underwent some dynamic morphological changes throughout the year. These changes were linked to the tissues and depended on the sexual cycle. The lamina propria highly regressed throughout the oviduct during the sexual rest, increased during the preparation phase, and a renewal of this tissue was observed in reproductive months. These results are in accordance with the histological observations, showing variable thickness of lamina propria among the months. More 
precisely, the lamina propria is narrow and dense during sexual rest and more or less thick according to the sections during the reproductive phase. In the pars utera, the proliferation-to-apoptotic ratio showed a strong predominance of cell proliferation from September until February, explaining the significant increase of the diameter of this segment at reproduction.

The cell composition of the epithelium was also noted to undergo seasonal variations. Secretory cells were the most represented epithelial cells in the pars recta. In this anterior part, both proliferating and apoptotic cells were counted more frequently over the breeding period than preparation, and on preparation than resting period. In the middle and posterior parts of the oviduct, apoptosis increased with proliferation after a regression during sexual rest. This feature could be explained by the holocrine activity of these gland cells, the secretion of which constitutes the egg gangues, and it is consistent with previous histological observations. The egg gangue is composed of two parts: (i) the histochemical composition of the internal part situated against the egg is the same glycoproteic granulations found in the secretory cells of the pars convoluta, and (ii) the composition of the external part looks like the acidic and sulphated proteoglycans granulations found in the secretory cells of pars utera (Raquet et al. 2011). After the passing of the egg, the oviduct wall was distended, and the number of cell granulations decreased in gland cells. As regards the goblet cells in the pars convoluta, the MarchAugust period was characterised by regression, the September-October period by a cellular turn-over, and November-February by an important cell proliferation. Ciliated cells were distributed heterogeneously in different parts of the oviduct, the pars recta contained few ciliated cells unlike the pars convoluta and pars utera. The role of these cells during breeding is particularly important in the middle and posterior parts of the oviduct, for they facilitate the transit of eggs after fertilisation occurring probably in the anterior part of the oviduct, like in other caecilian species (Exbrayat, 2006a). In this study, we observed ciliated cells undergoing a strong regression in both the pars convoluta and pars utera during the period of sexual rest, then dividing and specialising during the sexual preparation and breeding periods.

Neither egg storage nor sperm accumulation were observed in Boulengerula taitana studied here. According to available data, this situation could be general in caecilians (Exbrayat, 2006a).

These observations confirm that the genital tract of Boulengerula taitana is a dynamic organ with seasonal variations. The processes involved in the annual renewal of the oviduct tissues are likely to relate to the cyclical changes during ovarian maturation. Each part of the oviduct possesses its own cell morphology and functional properties allowing the fertilisation and transit of eggs during the breeding period. This cyclic regulation, involving proliferative and apoptotic activities, can be related to ovarian steroid hormone levels. Indeed, preliminary studies showed the presence of $\alpha$ and $\beta$ oestrogen receptors and progesterone receptors in the three parts of the oviduct (Raquet et al. 2013). Such receptors were also found both in the ovaries and oviducts of the viviparous species Typhlonectes compressicauda (Exbrayat, 2014). Moreover, other studies pointed to the role of ovarian hormones and testosterone on the proliferation of the oviduct in several amphibians, including anurans and salamanders (Pierantoni et al. 1984; d'Istria et al. 1985; Skliris et al. 2008). Therefore, it is likely that the hormonal balance in Boulengerula taitana affects the sexual cycle and the dynamic changes in the oviduct, as described in other amphibians. 


\section{ACKNowledgements}

We would like to thank Patrick Malonza, field assistants and land-owners in the Taita Hills, Kenya for facilitating the collection of material used in this study.

\section{REFERENCES}

D’Istria, M., F. Citarella, G. Delrio \& G. Chieffi. 1985. Role of androgen in amphibian reproduction. In B. Lofts \& W.N. Holmes (Eds), Current Trends in Comparative Endocrinology. Hong Kong University Press, Hong Kong, pp. 243-245.

EXBRAYAT, J.M. 1989. Cycle de reproduction et gestation chez Typhlonectes compressicaudus, Amphibien Gymnophione: nouvelles données. Bull. Soc. Zool. Fr. 114(1): 43.

Exbrayat, J.M. 2006a. Modes of parity and oviposition. In J.M. Exbrayat (Ed.), Reproductive Biology and Phylogeny of Gymnophiona (Caecilians), Science Publishers, Enfield, vol. 5, pp. 303-324.

EXBRAYAT, J.M. 2006b. Endocrinology of reproduction in Gymnophiona. In J.M. EXBRAYAT (Ed.), Reproductive Biology and Phylogeny of Gymnophiona (Caecilians), Science Publishers, Enfield, vol. 5, pp. 183-230.

EXBRAYAT, J.M. 2013. Histochemical methods. In J.M. ExBrayat (Ed.), Histochemical and Cytochemical Methods of Visualization. CRC Press, Boca Raton, FL, pp. 59-138.

EXBRAYAT, J.M. 2014. From bony to mammals: reproductive cycles in vertebrates, hormones and hormone-receptors. Receptors Clin. Investig. 1: e86.

Gomes, A.D., R.G. Moreira, C.A.A. Navas, M.M. Antoniazzi \& C. Jared. 2012. Review of the reproductive biology of caecilians (Amphibia, Gymnophiona). South Am. J. Herp. 7(3): 191-202.

MalonZA, P.K. \& G.J. Measey. 2005. Life history of an African caecilian: Boulengerula taitanus, Loveridge 1935 (Amphibia Gymnophiona Caeciilidae). Trop. Zool. 18(1): 49-66.

Masood-PARVEez, U. \& V.B. NADKARNI. 1991. Morphological, histological, histochemical and annual cycle of the oviduct in Ichthyophis beddomei (Amphibia: Gymnophiona). J. Herp. 25(2): 234-237.

Measey, G.J., M. Smita, R.S. Beyo \& O.V. Oommen. 2008. Year-round spermatogenic activity in an oviparous subterranean caecilian, Boulengerula taitanus Loveridge 1935 (Amphibia Gymnophiona Caeciliidae). Trop. Zool. 21: 109-122.

Pierantoni, R., L. Iela, G. Delrio \& R.K. Rastogi. 1984. Seasonal plasma sex steroid levels in the female Rana esculenta. Gen. Comp. Endocr. 53(1): 126-134.

Raquet, M., J. Measey \& J.M. Exbrayat. 2011. Premières observations histologiques de l'oviducte de Boulengerula taitana, Loveridge, 1935, Amphibien Gymnophione. Rev. Fr. Histotechnol. 24: 29-38.

Raquet, M., J. Measey \& J.M. Exbrayat. 2013. Mise en évidence des récepteurs des oestrogènes $\alpha$ et $\beta$ dans les ovaires de Boulengerula taitana amphibien gymnophione. Rev. Fr. Histotechnol. 26: 99-105.

Raquet, M., G.J. Measey \& J.M. Exbrayat. 2015. Annual variation of ovarian structures of Boulengerula taitana (Loveridge 1935), a Kenyan caecilian. Afr. J. Herpetol., 64: 116-134.

Rodriguez, M. \& J. Schaper. 2005. Apoptosis: measurement and technical issues. J. Mol. Cell. Cardiol. 38(1): 15-20.

Skliris, G.P., E. Leygue, P.H. Watson \& L.C. Murphy. 2008. Estrogen receptor $\alpha$ negative breast cancer patients: estrogen receptor $\beta$ as a therapeutic target. J. Ster. Biochem. Mol. Biol. 109(1-2): 1 .

Steffl, M., M. Schweiger, T. Sugiyama \& W.M. Amselgruber. 2008. Review of apoptotic and nonapoptotic events in nonciliated cells of the mammalian oviduct. Ann. Ant. 190: 46-52.

TAatJes, D.J., B.E. Sobel \& R.C. BudD. 2008. Morphological and cytochemical determination of cell death by apoptosis. Histochem. Cell Biol. 129(1): 33-43.

WAKE, M.H. \& R. DiCKIE. 1998. Oviduct structure and function and reproductive modes in Amphibians. J. Experim. Zool. 282: 477-506.

WAKE, M.H. 1970. Evolutionary morphology of the caecilian urogenital system. Part II. The kidney and the urogenital ducts. Acta Anat. 75: 321-358. 